\title{
LATVIAN CITIZENS' KNOWLEDGE ABOUT DIETARY FIBRE
}

\author{
Dace Kḷava ${ }^{1, \#}$, Evita Straumite ${ }^{1}$, Zanda Krūma ${ }^{1}$, and Raquel P. F. Guiné ${ }^{2}$ \\ ${ }^{1}$ Faculty of Food Technology, Latvia University of Agriculture, 22 Rĩgas Str., Jelgava, LV-3001, LATVIA \\ ${ }^{2}$ Escola Superior Agrária de Viseu, Quinta da Alagoa, Estrada de Nelas, Ranhados, 3500-606 Viseu, PORTUGAL \\ \# Corresponding author e-mail: dace.klava@llu.Iv
}

Communicated by Inga Ciproviča

\begin{abstract}
The positive benefits of dietary fibre (DF) include regulation of the intestinal transit, prevention of risk or treatment of diabetes, and prevention of cardiovascular diseases, colon cancer, and obesity. The aim of this study was to collect information on knowledge about dietary fibre of citizens of Latvia. The questionnaire consisted of 22 questions. Its aim was to evaluate knowledge in three distinct areas: six concerning knowledge about food fibres; six - about the relation between fibres and various foods, and ten about the relation between fibres and diseases. The methodological study was conducted involving 231 participants, of which $83.5 \%$ were female and $16.5 \%$ male, aged between 18 and 80 years. The respondents were selected by convenience, and they differed in age, literacy, gender, geographical area of residence, and included people from different cities and smaller villages. $67 \%$ of the respondents considered that consumption of sufficient amounts of fibres can prevent or treat different diseases. $85 \%$ of respondents noted that legumes (peas, beans) are a source of fibres, but that it was more possible to take up the fibre with a combination of vegetables and animal products. The questionnaire revealed that respondents are aware of the benefits of fibre consumption for promoting health and treating some diseases.
\end{abstract}

Key words: dietary fibre, knowledge, questionnaire, Latvia citizens.

\section{INTRODUCTION}

To succeed in a highly competitive market, food companies must develop new successful products valued by consumers (Grunert et al., 1996; Stewart-Knox and Mitchell, 2003; Barrena and Sinchez, 2012). Development of new technologies or products is driven by advancements in technology, consumer priorities not taken into consideration before the product stage. The public may have difficulties in understanding and/or appreciating the benefits of the new technologies unless they are presented concrete product-related benefits. The consumer and food scientists do not use the same language. Food scientists enter discussions about healthy products, products rich with dietary fibre, but consumers not always understand these terms. The American Association of Cereal Chemists in 2001 (Anonymous, 2001) defined dietary fibre as "the edible parts of plants or analogous carbohydrates that are resistant to digestion and absorption in the human small intestine with complete or partial fermentation in the large intestine". Some authors, such as Yan et al. (2015), define dietary fibre (DF) as composed of a mixture of compounds that include carbohydrate polymers as well as non-carbohydrate components, including cellulose, hemicelluloses, pectins, gums, mucilages, and lignin.
Dietary fibre can also impart some functional properties to foods, e.g., increase water holding capacity, oil holding capacity, emulsification and/or gel formation. Indeed, we shall illustrate that dietary fibre incorporated into food products (bakery products, dairy, jams, meats, soups) can modify textural properties, avoid synaeresis (the separation of liquid from a gel caused by contraction), stabilise high fat food and emulsions, and improve shelf-life (Elleuch et al., 2011).

Consumption of grain products and particularly those made from wholegrain are associated with various health benefits (Jacobs et al., 1999; Liu et al., 1999). These benefits can be achieved either by consuming wholegrain products or alternatively can be derived from changing the composition of the grain to include more beneficial components (Poutanen et al., 2008). Whether benefits are to be achieved through the consumption of wholegrain or the consumption of such functional grain products, in order to have any impact on health it is necessary for consumers to eat such types of foods. Cereal grain bran fractions, seed coat and cotyledons of legumes, and endosperm cell walls are rich sources of DFs. Those DFs that selectively promote probiotics (living microorganisms that confer health benefit on the host) and benefit host health are prebiotics (Bultosa, 2016). 
Association between intake of dietary fibre and reduction in incidence of colorectal cancer is debatable, but it has been shown in a large epidemiological trial that dietary fibre from grains and cereals gives a protective function (Peters et al., 2003), confirming the statement of the European Cancer Prevention consensus panel (Anonymous, 1997) that high intake of cereal fibre may reduce the risk of colorectal cancer (Grasten et al., 2007). The current trend is towards diets that include a greater amount of plant foods as these are implicated in the maintenance and/or improvement of health (Rodríguez et al., 2006). However, despite the beneficial effects mentioned above, there is also evidence of some negative health effects resulting from the intake of fibre. For example, fibre can produce phytobenzoates, which can induce a decrease of proteins in the absorption and digestion process (Martinho et al., 2013).

The dietary fibres were one of the most attractive themes in nutrition and public health in the second half of the twentieth century, being the stimulus for a large number of epidemiological studies at different levels: physiological, analytical, and technical. In that way it served as catalyst for the advancement of knowledge about the causes of several diseases, especially those connected to the large intestine or diabetes, and have contributed to set targets valuable for defining a healthy diet both by the food industry and by legalisation (Cummings et al., 2004; Martinho et al., 2013). The aim of this research was to survey knowledge about dietary fibre by citizens of Latvia.

\section{MATERIALS AND METHODS}

Participants and study design. To achieve the objective of this study a survey was made by means of a questionnaire comprised of open and closed questions, in order to obtain some qualitative information on knowledge of Latvian citizens about dietary fibre. The questionnaire consisted of 22 questions (Table 1), the aim of which was to evaluate knowledge in three distinct areas: six concerning knowledge about food fibres; six - about the relation between fibres and variety of foods, and ten about the relation between fibres and diseases.

They are all presented in the ordinal Likert scale according to the following answer format: 1 - strongly disagree; 2 disagree; 3 - neither agree nor disagree; 4 - agree; and 5 strongly agree.

The questionnaire was completed between October and December of year 2014, and a total of 231 filled-in questionnaires were obtained by respondents of which $83.5 \%$ were female and $16.5 \%$ male, aged between 18 and 80 years.

Statistical analysis. The mean and standard deviations and $p$ values were processed by mathematical and statically methods. The data were subjected to one way analysis of variance (ANOVA). Significance was defined at $p<0.05$.

\section{DESIGN OF QUESTIONNAIRE}

\begin{tabular}{|c|c|}
\hline Item & Complete question \\
\hline Q.1 & Only plant foods have fibre. \\
\hline Q.2 & $\begin{array}{l}\text { Foods of animal origin such as meat, eggs, and dairy products } \\
\text { contain no fibres (unless added). }\end{array}$ \\
\hline Q.3 & $\begin{array}{l}\text { According to the World Health Organisation, the average adult } \\
\text { should eat } 25 \mathrm{~g} \text { of fibre per day. }\end{array}$ \\
\hline Q.4 & $\begin{array}{l}\text { Whole foods (pasta, rice, bread, cereal...) have less fibre than } \\
\text { non-whole foods. }\end{array}$ \\
\hline Q.5 & Unpeeled fruits have less fibre than peeled ones. \\
\hline Q.6 & Dietary fibres are classified into soluble and insoluble. \\
\hline Q.7 & Dietary fibres are only in plant foods. \\
\hline Q.8 & Dietary fibres are only in animal foods. \\
\hline Q.9 & Dietary fibres may originate in plant and animal foods. \\
\hline Q.10 & $\begin{array}{l}\text { Dietary fibres have calories, and so they provide energy to the } \\
\text { organism when ingested. }\end{array}$ \\
\hline Q.11 & $\begin{array}{l}\text { Legumes (peas, beans), cereals, and fruits are foods that are very } \\
\text { rich in dietary fibre. }\end{array}$ \\
\hline Q.12 & $\begin{array}{l}\text { The average consumption of dietary fibres is higher in urban areas } \\
\text { than in rural areas. }\end{array}$ \\
\hline Q.13 & $\begin{array}{l}\text { Eating dietary fibres in appropriate amounts can prevent and/or } \\
\text { treat diseases. }\end{array}$ \\
\hline Q.14 & Fibres can prevent and/or treat cardio-vascular diseases. \\
\hline Q.15 & Fibres can prevent and/or treat cholesterol. \\
\hline Q.16 & Fibres can prevent and/or treat bowel cancer. \\
\hline Q.17 & Fibres can prevent and/or treat obesity. \\
\hline Q.18 & Fibres can prevent and/or treat breast cancer. \\
\hline Q.19 & Fibres can prevent and/or treat constipation. \\
\hline Q.20 & Fibres can prevent and/or treat vision problems. \\
\hline Q.21 & $\begin{array}{l}\text { Fibres can prevent and/or treat the deficiency of vitamins and } \\
\text { minerals. }\end{array}$ \\
\hline Q.22 & Fibres can prevent and/or treat diabetes. \\
\hline
\end{tabular}

\section{RESULTS}

The geographical coverage was throughout Latvia, from the north to the south. The respondents were selected by convenience, of different age, literacy, gender, geographical area of residence, and including people from different rural and urban areas (Table 2).

All of the respondents were over 18 years old, the majority $(29.9 \%)$ were in the range 31 to 40 years, followed by $25.9 \%$ who were aged between 41 and 50 years. The pro-

Table 2

STATISTICS ON RESPONDENTS

\begin{tabular}{l|c|c|c|c}
\hline $\begin{array}{c}\text { Regions of } \\
\text { Latvia }\end{array}$ & $\begin{array}{c}\text { Number of } \\
\text { respondents }\end{array}$ & $\begin{array}{c}\text { Percentage, } \\
\%\end{array}$ & $\begin{array}{c}\text { Number of } \\
\text { respondents, } \\
\text { male/female }\end{array}$ & $\begin{array}{c}\text { Average age } \\
\text { of respondents }\end{array}$ \\
\hline Latgale & 19 & 8 & $10 / 9$ & 35 \\
Zemgale & 81 & 35 & $7 / 74$ & 41 \\
Kurzeme & 32 & 14 & $2 / 30$ & 40 \\
Vidzeme & 38 & 16 & $8 / 30$ & 41 \\
Rīga & 61 & 27 & $11 / 50$ & 37 \\
Total & 231 & 100 & $38 / 193$ & 38
\end{tabular}



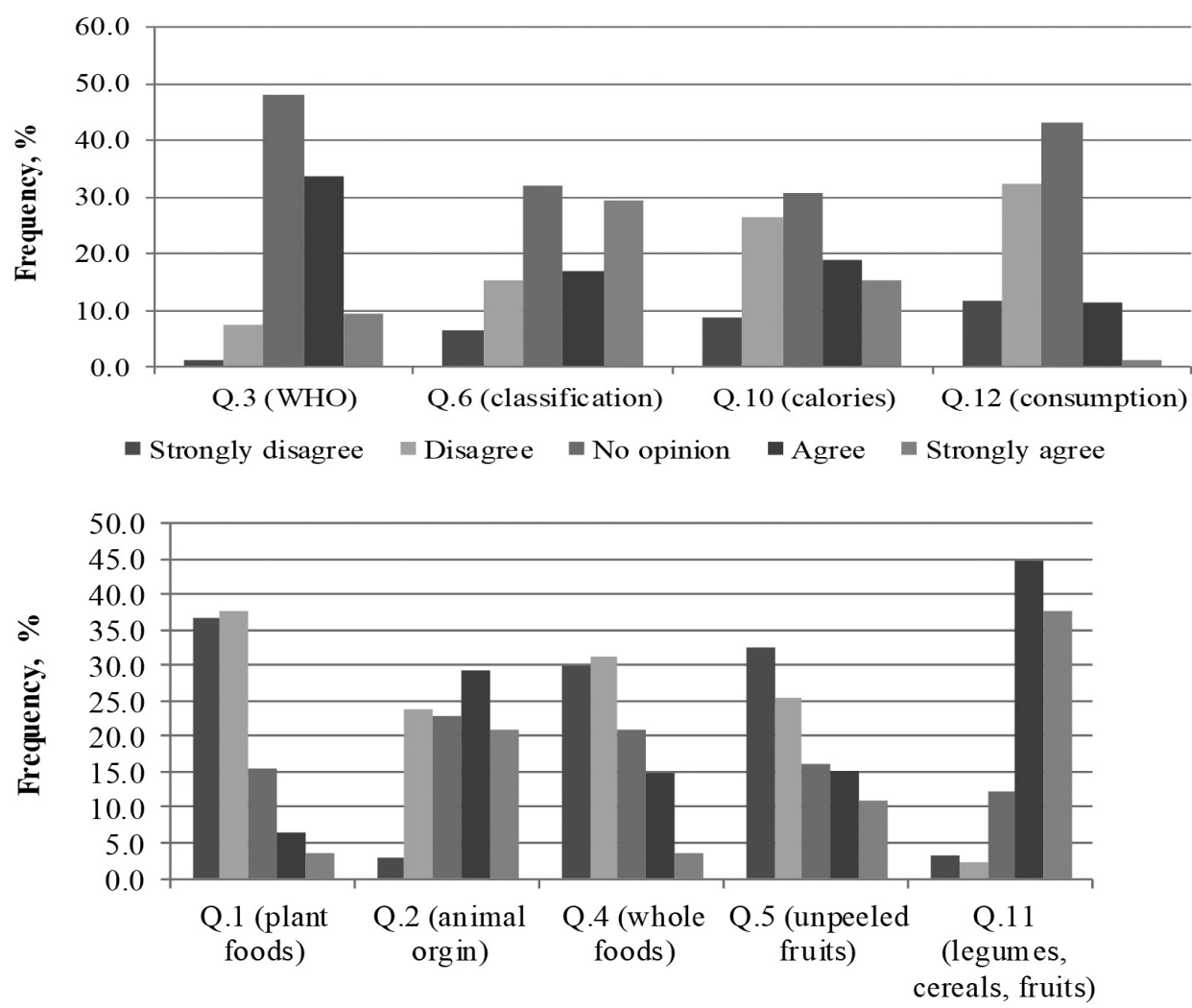

- Strongly disagree $\square$ Disagree $\square$ No opinion $\square$ Agree $\square$ Strongly agree
Fig. 1. Perception of Latvian citizens about dietary fibres. portion of those aged between 18 and 30 was $23.7 \%$, between 51 and 60 years $-14.9 \%$ and over 60 years $-5.6 \%$. Considering the place of living, a large majority, $65.3 \%$ lived in urban areas, and $34.6 \%$ lived in rural areas.

The respondent perception and knowledge about overall questions about DF are summarised in Figure 1.

Latvian respondents lacked good knowledge about the DF classification (soluble and insoluble), calories of DF and the recommended DF daily intake (Fig. 1).

The knowledge of respondents about the relationship between fibre and variety of foods is summarised in Figure 2, which shows that the respondents know that the respective food products are good sources of dietary fibre.

The results (Fig. 3) showed that respondents did not have a unified view about fibres recourses in food. Most of them agreed that plant and animal foods are fibre-rich products.

Knowledge of the relation between fibre and diseases is shown in Table 3. Knowledge of respondents about the relation between fibre rich foods and diseases was intermediate. They very well understood the relation between fibre and regulation of cholesterol level and treatment of constipation. On the other diseases, the opinion was contradictory.

\section{DISCUSION}

Over the past 200 years, intake of dietary fibre, which has always been a significant part of the human diet, has gradu-

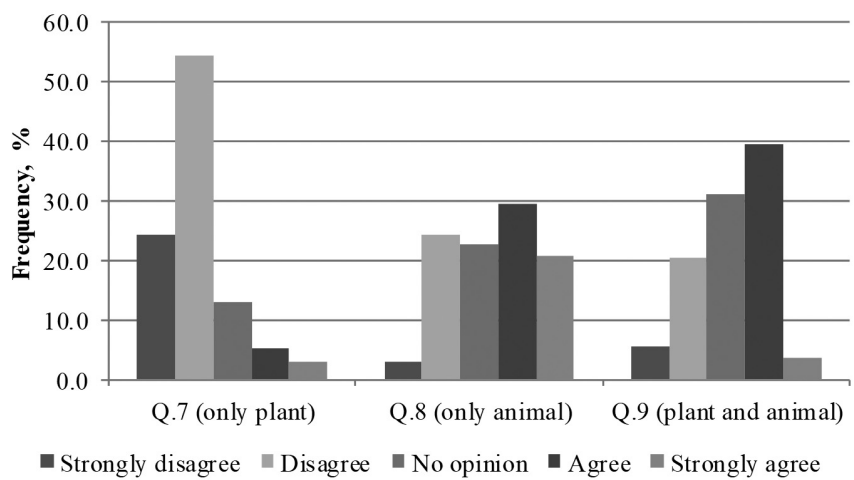

Fig. 3. Respondent perception about relation between fibres and plant and animal foods

ally decreased (Kendall et al., 2010). It was interesting to determine Latvian respondents' knowledge on the recommendations of the World Health Organisation (WHO) daily intake of DF (Table 1, Question 3). The majority of respondents $(48 \%)$ had no opinion (Fig. 1) on the WHO recommendation stating that an adult should consume on average $25 \mathrm{~g}$ DF per day. 8.6\% of the respondents did not know how much DF should be consumed by an average adult per day. Fibre recommendations were based on studies that show an increased risk for heart disease when diets low in fibre are consumed. The recommended daily intake of total fibre for adults 50 years and younger was set at $38 \mathrm{~g}$ for men and $25 \mathrm{~g}$ for women, while for men and women over 50 years it was set at 30 and $21 \mathrm{~g}$ of fibre per day, respectively, due to decreased consumption of food (Slavin, 2003). Information on the daily intake of DF in the scientific and public space 
STATISTICS REGARDING THE RELATIONSHIP BETWEEN FIBRE AND DISEASES

\begin{tabular}{c|c|c|c|c|c|c}
\hline \multirow{2}{*}{ Item } & \multicolumn{5}{|c|}{ Respondents answer, \% } & Average the \\
\cline { 2 - 6 } & $\begin{array}{c}\text { Strongly } \\
\text { disagree } \\
(1)\end{array}$ & $\begin{array}{c}\text { Disagree } \\
(2)\end{array}$ & $\begin{array}{c}\text { No opin- } \\
\text { ion(3) }\end{array}$ & $\begin{array}{c}\text { Agree } \\
(4)\end{array}$ & $\begin{array}{c}\text { Strongly } \\
\text { agree (5) }\end{array}$ & Likert scale \\
\hline Q.13 & 0.4 & 3.9 & 26.4 & 53.7 & 15.6 & $3.80 \pm 0.76$ \\
Q.14 & 1.3 & 7.3 & 35.9 & 46.8 & 8.7 & $3.54 \pm 0.80$ \\
Q.15 & 0.0 & 1.7 & 25.5 & 59.4 & 13.4 & $3.84 \pm 0.66$ \\
Q.16 & 2.6 & 7.8 & 37.7 & 41.1 & 10.8 & $3.49 \pm 0.88$ \\
Q.17 & 0.4 & 3.0 & 20.8 & 53.7 & 22.1 & $3.94 \pm 0.77$ \\
Q.18 & 6.9 & 19.9 & 59.8 & 11.7 & 1.7 & $2.81 \pm 0.79$ \\
Q.19 & 1.3 & 1.3 & 17.3 & 47.6 & 32.5 & $4.09 \pm 0.81$ \\
Q.20 & 11.3 & 26.0 & 50.6 & 10.8 & 1.3 & $2.65 \pm 0.86$ \\
Q.21 & 6.4 & 19.1 & 33.3 & 35.1 & 6.1 & $3.15 \pm 1.01$ \\
Q.22 & 3.0 & 9.5 & 48.9 & 33.8 & 4.8 & $3.28 \pm 0.82$
\end{tabular}

could be used to promote the knowledge of Latvian respondents. The results of the questionnaire showed that Latvian women have more knowledge about the recommended daily intake of DF compared to men $(p<0.05)$.

Dietary fibre can be categorised into soluble and insoluble, according to its solubility in water, and both types are present in most plant foods (Elleuch et al., 2011). Cellulose and lignin, which are structural parts of plants, belong to the category of insoluble fibre, since they do not dissolve in water and are not metabolised by intestinal bacteria. On the other hand, pectin, gums, and mucilages, which exist within and around the plant cells, belong to the soluble fibre since they are water soluble (acquiring a gel-like structure) and fermentable by colonic bacteria (Guine et al., 2014). Answers to Question 6 (dietary fibres are classified into soluble and insoluble) showed that $22.1 \%$ of respondents do know about solubility of fibres, $32.0 \%$ did not have clear opinion about classification of DF (Fig. 1). $45 \%$ of respondents agreed/strongly agreed that dietary fibres are classified into soluble and insoluble. Only $21 \%$ of Portuguese respondents have good knowledge about DF classification (Martinho et al., 2013), thus it can be concluded that Latvian citizens are better informed about solubility of fibres.

Regarding the knowledge about the relationship between DF and energy, the average response was $2.81 \pm 1.01$ on the Likert scale corresponding to a neither agree nor disagree (score 3). Regarding Question 10 (DF have calories, and so they provide energy to the organism) only $27.69 \%$ of respondents agreed and $30.7 \%$ responded neither agree nor disagree to this statement. This does correspond to good understanding, because according EU Regulation No. $1169 / 2011$ on the provision of food information to consumers, DF is a energy source from which through metabolic processes $2 \mathrm{kcal} \cdot \mathrm{g}^{-1}\left(8 \mathrm{~kJ} \cdot \mathrm{g}^{-1}\right)$ are produced. Thus, knowledge about nutrition and energy value of fibre is insufficient, and active communication to the public could improve the situation.
Regarding the knowledge about DF, the respondents revealed on average a positive grade in the level of knowledge in Latvia, although low, which means that still some measures should be adopted to inform the population about DF and its role as a component of a healthy diet. The level of education also had a significant effect $(p<0.05)$; participants with higher education (university level) demonstrated a higher level of knowledge.

The most widespread, extensively advertised, and consumed DF products are those derived from cereals (breakfast cereals, bakery products, biscuits, etc.). However, over the past decade, a greater amount of dietary fibre materials from fruits (citrus, apple, and others) is being introduced in the market (Nandi and Ghosh, 2015). Dietary fibre has been introduced via vegetable intake from the beginning of time and has been recognised as having a low caloric value but providing important health benefits (Zhu et al., 2015). Knowledge and understanding of consumers about dietary fibre in food are very important for food and nutrition scientists and for producers.

Regarding Question 11, 82\% respondents agreed (agree or agree strongly) that legumes (peas, beans), cereals and fruits are foods that are very rich in DF (Fig. 2). Studies described by Dahl and Stewart (2015) and Martinho et al. (2013) corroborate the opinion of Latvian respondents, in that it is very good to know about DF amounts in different raw materials. On Question 4, 61.1\% respondents strongly disagree or disagree that whole foods (pasta, rice, bread, cereals) have less fibre than non-whole foods (Fig. 2). This shows that the public in Latvia has sufficient information about wholegrain products, and that consumers are knowledgeable. However, respondents were not so confident about DF in the foods of animal origin - the Likert score for the statement was $1.77 \pm 0.70$, corresponding to disagreement (score under 3.0), thus indicating that most people still do not know the origin (only plant or only animal) of DF (Fig. 3). Therefore, in general Latvian citizens are aware that fibre does not have primary origin from animal foods, which is consistent with research of Martinho et al. (2013) about DF knowledge of Portugal citizens.

Positive benefits of DF are associated with the regulation of the intestinal transit, and prevention or treatment of diabetes, cardiovascular diseases, and regulation of colon cancer and obesity. Nutritional recommendations for diabetes frequently include modest weight loss and increase in fibre intake. In addition, current guidelines for the prevention of type 2 diabetes include an increase in the total dietary fibre intake (Bantle et al., 2008), since prospective studies have observed reduced diabetes risk with high cereal fibre and whole grain consumption (Liu, 1999). Considering the responses "neither agree nor disagree" (Table 3), respondents are not sure about DF and treatment of breast cancer $(59.8 \%)$, vision problems $(50.6 \%)$, diabetes $(48.9 \%)$, and bowel cancer $(37.7 \%)$. Respondents have a wrong idea about the effect of fibre to treat vision problems (Likert scale score $-2.65 \pm 0.86)$. There is no evidence whatsoever about any benefits of ingesting dietary fibre and im- 
provement of vision, but this question was aimed at accessing the knowledge of the population about this issue.

A significant difference $(p<0.05)$ was not found between knowledge of respondents about DF and disease. The obtained results (Table 3) indicate that Latvian respondents associate DF with the cholesterol level, regulation of obesity, and treatment of constipation. The statement of these answers on the Likert scale was $3.84 \pm 0.66$ (Question 15), $3.94 \pm 0.77$ (Question 17) and $4.09 \pm 0.81$ (Question 19) for the associated diseases.

\section{CONCLUSION}

Latvian respondents revealed on average a positive level of knowledge about DF, however, some measures still must be adopted to inform the citizens about DF and its role as a component of a healthy diet.

This study provided valuable information regarding the level of information of a wide range of respondents about the health benefits of an adequate intake of dietary fibre.

The questionnaire revealed that respondents are aware of the benefits of fibre consumption for promoting health and treating some dessease.

\section{ACKNOWLEDGEMENTS}

This work was prepared in the ambit of the multinational project from CI\&DETS Research Centre (IPV - Viseu, Portugal) with reference PROJ/CI\&DETS/2014/0001.

\section{REFERENCES}

Anonymous (1997). Consensus meeting on cereals, fiber and colorectal and breast cancers. ECP consensus panel on cereals and cancer. Eur. J. Cancer Prev., 6, 512-514.

Anonymous (2001). The definition of dietary fiber. American Association of Cereal Chemists Report: Dietary Fiber Technical Committee. Cereal Foods World, 46 (3), 112-126.

Dahl, W. J., Stewart, M. L. (2015). Position of the Academy of Nutritions and Dietetics: Health implications of dietary fiber. J. Acad. Nutr. Diet. 115 (11), 61-70.

Bantle, J. P., Wylie-Rosett, J., Albright, A. L., Apovian, C. M., Clark, N. G., Franz, M. J., Hoogwert, B. J., Lichtenstein, A. H., Mayer-Davis, E., Mooradian, A. D., Wheder, M. L. (2008). Nutrition recommendations and interventions for diabetes: A position statement of the American Diabetes Association. Diabetes Care, 31 (1), 61-78.

Barrena, R., Sánchez, M. (2012). Personal consumer values and novel food acceptance. Food Qual. Prefer., 27, 72-84.

Bultosa, G. (2016). Functional Foods: Dietary Fibers, Prebiotics, Probiotics, and Synbiotics. Academic Press, Elsevier, United Kingdom. $500 \mathrm{pp}$.
Cummings, J. H., Edmond, L. M., Magee, E. A. (2004). Dietary carbohydrates and health: Do we still need the fibre concept? Clin. Nutrit., 1, 5-17.

Elleuch, M., Bedigian, D., Roiseux, O., Besbes, S., Blecker, C., Attia, H. (2011). Dietary fibre and fibre-rich by-products of food processing: Characterisation, technological functionality and commercial applications. A review. Food Chem., 124 (2), 411-421.

Grasten, S. M., Juntunen, K. S., Matto, J., Mykkanen, O. T., Nezami, H. E., Adlercreutz, H., Poutanen, K. S., Mykkänen, H. M. (2007). High-fiber rye bread improves bowel function in postmenopausal women but does not cause other putatively positive changes in the metabolic activity of intestinal microbiota. Nutr. Res., 27, 454-461.

Grunert, K. G., Larsen, H. H., Madsen, T. K., Baadsgaard, A. (1996). Market Orientation in Food and Agriculture. Kluwer Academic Publishers, Boston. 283 pp.

Guine, R., Martinho, C., Barroca, M. J., Viseu, C. (2014). Knowledge and attitudes regarding dietary fibres: A consumer survey in Portuguese population. J. Basic Appl. Res. Int., 1 (1), 10-12.

Jacobs, D. R., Meyer, K. A., Kushi, L. H., Folsom, A. R. (1999). Is whole grain intake associated with reduced total and cause-specific death rates in older women? The Iowa women's health study. Amer. J. Clin. Nutr., 89, 322-329.

Kendall, C. W. C., Esfahani, A., Jenkins, D. J. A. (2010). The link between dietary fibre and human health. Food Hydrocoll., 24, 42-48.

Liu, S., Stampfer, M. J., Hu, F. B., Giovannucci, E., Rimm, E. B., Manson, J. E., Hennekens, C. H., Willett, W. C. (1999). Whole grain consumption and risk of coronary heart disease: Results from the nurse's health study. Amer. J. Clin. Nutr. 70, 412-419.

Martinho, C. A. C., Correia, A. C., Goncalves, F. M., Abrantes, J. L., Carvalho, R., Guiné, R. P. F. (2013). Study about the knowledge and attitudes of the Portuguese population about food fibres. Curr. Nutr. Food Sci., 9 (3), 180-188.

Nandi, I., Ghosh, M. (2015). Studies on functional and antioxidant property of dietary fibre extracted from defatted sesame husk, rice bran and flaxseed. Bioact. Carbohydrates Diet. Fibre., 5 (2), 129-136.

Peters, U., Sinha, R., Chatterjee, N., Subar, A. F., Ziegler, R. G., Kulldorff, M., Bresalier, R., Weissfeld, J. L., Flood, A., Schatzkin, A., Hayes, R. B. (2003). Dietary fiber and colorectal adenoma in colorectal cancer early detection programme. Lancet, 361, 1491-1495.

Poutanen, K., Shepherd, R., Shewry, P., Delcour, J. A., Bjorck, I., Van der Kamp, J. W. (2008). Beyond whole grain: the European HEALTHGRAIN project aims at healthier cereal foods. Cereal Foods World, 53 (1), 32-35.

Rodríguez, R., Jiménez, A., Fernández-Bolaños, J., Guillén, R., Heredia, A. (2006). Dietary fibre from vegetable products as source of functional ingredients. Trends Food Sci. Technol., 17, 3-15.

Slavin, J. (2003). Impact of the proposed definition of dietary fiber on nutrient databases. J. Food Compos. Anal., 16 (3), 287-291.

Stewart-Knox, B., Mitchell, P. (2003). What separates the winners from the losers in new food product development? Trends Food Sci. Technol., 14 (1-2), 58-64.

Yan, X., Ye, R., Chen, Y. (2015). Blasting extrusion processing: The increase of soluble dietary fiber content and extraction of soluble-fiber polysaccharides from wheat bran. Food Chem., 180, 106-115.

Zhu, F., Du, B., Zheng, L., Li, J. (2015). Advance on the bioactivity and potential applications of dietary fibre from grape pomace. Food Chem., 186, 207-212. 


\section{LATVIJAS IEDZĪVOTĀJU ZINĀŠANAS PAR ŠKIEDRVIELĀM}

Škiedrvielu uzņemšana asociējas ar to pozitīvo ietekmi uz zarnu trakta peristaltiku, diabēta slimniekiem cukura līmeņa regulāciju, sirds un asinsvadu slimību novēršanu, kā arī svara regulēšanai. Pētījuma mērkis bija noskaidrot Latvijas iedzīvotāju zināšanas par škiedrvielām. Pētījuma ietvaros tika izveidota aptaujas anketa ar 22 jautājumiem, kas iedalīti trīs grupās: seši jautājumi — zināšanas par škiedrvielām; seši — kopsakarības starp šķiedrvielām un pārtikas produktu grupām un desmit — kopsakarības starp škiedrvielām un saslimšanām. $67 \%$ respondentu uzskata, ka, uzṇemot pietiekamā daudzumā škiedrvielas, ir iespējams novērst dažādas saslimšanas. 85\% respondentu atzīmējuši, ka pākšaugi ir bagātīgs šḳiedrvielu avots, bet vairāk škiedrvielu iespējams uzṇemt, kombinējot augu un dzīvnieku valsts produktus. Iegūtie rezultāti norāda, ka respondenti šķiedrvielas uzturā asociē ar holesterīna līmeņa regulēšanu, aptaukošanās un aizcietējumu samazināšanu. 